\title{
新型冠状病毒肺炎(COVID-19)疫情持续中的治愈率/ 病死率估计
}

习英 ${ }^{1 \dagger}$, 刘晓筠 ${ }^{3 \dagger}$, 汪涛 ${ }^{2 \dagger}$, 曾熦菲 ${ }^{5}$, 董臣 ${ }^{6}$, 章元明 ${ }^{7}$, 周昌龙 ${ }^{8}$, 余璇 ${ }^{2}$, 刘定富 $4^{*}$, 胡中立 $2^{*}$

1. 重庆文理学院园林与生命科学学院, 重庆 402160;

2. 武汉大学生命科学学院, 武汉 430072;

3. 武汉问道信息技术有限公司, 武汉 430040;

4. 湖北省农业科学院, 武汉 430064;

5. 南方科技大学医学院, 深圳 518055 ;

6. 河南工业大学生物工程学院, 郑州 450001;

7. 华中农业大学植物科学技术学院, 武汉 430070;

8. 重庆医科大学附属永川医院, 重庆 402160

$\dagger$ 同等贡献

* 联系人, E-mail: wonderlau@126.com; huzhongli@whu.edu.cn

2020-02-28 收稿, 2020-03-27 修回, 2020-04-02 接受, 2020-04-03 网络版发表

摘要 由新型冠状病毒 SARS-CoV-2 引起的疫情, 已成为全球关注的紧急公共卫生事件. 然而, 由于疫情持续中 的数据不断变化, 对于疫情的治愈率和病死率尚无较为科学的计算方法. 本研究提出了一种估计 COVID-19 治愈 率和病死率的方法, 以给定日累计出院人数与给定日累计出院人数和 $j$ 日前累计死亡人数之和的比值来估计治愈 率, 此外, 病死亡率也可以据此估计. 当 $j=9$ 时, 新型冠状病毒肺炎全国的治愈率估计值为 $95.8 \%$ 左右, 而新型冠 状病毒肺炎全国的病死率估计值为 $4.2 \%$ 左右, 这比 2003 年 SARS 疫情中国大陆的病死率 $6.6 \%$ 低; 武汉市的治愈 率估计值为 $94.5 \%$ 左右, 而新型冠状病毒肺炎武汉市的病死率估计值则在 $5.5 \%$ 左右。这种估计治愈率的方法可用 于评价不同医疗方案和不同地区的治疗效果，对疫情的决策具有重要的参考价值和意义.

关键词 COVID-19, SARS-CoV-2, 治愈率, 病死率, 估计

2019年12月, 我国发生了由新型 冠状病毒SARS-CoV-2引发的疫情, 感 染人群增多, 传播范围不断扩大, 对公 共卫生安全形成了压力 ${ }^{[1]}$. 世界各国迅 速启动的关于新型冠状病毒肺炎 (COVID-19, 以下简称新冠肺炎)的病 毒学、流行病学及临床医学等相关研 究, 对疫病的防治起到了积极作 用 ${ }^{[2 \sim 11]}$. 由于同属冠状病毒, 公众习惯 性地将 COVID-19 与 SARS 进行比较, 尤其是最为关注治愈率或病死率数据.
2003 年 “非典”, 中国累计感染人数 5327 人, 累计死亡人数 349 人, 病死率 为 $6.5 \%$; 全球累计感染 8098 人, 累计 死亡人数 774 人, 病死率为 $9.6 \%{ }^{[12]}$. 然 而, 国家卫生健康委员会医政医管局 副局长焦雅辉 2 月 4 日在北京举办的发 布会上表示, 针对新冠肺炎患者治愈 率问题, 目前还没有一个明确的计算 公式 ${ }^{[13]}$. 目前, 卫计委公布的病死率 的计算是采用累计死亡人数与累计确 诊人数之比这种通行的方法来计算病
死率. 对于已经结束的疫情“非典”而 言是准确的. 但对于新冠肺炎这种未 知的并且正在持续的疫病, 这一估计 方法存在缺陷, 所得出的结果会让人 误解, 甚至会使决策者对未来的局势 做出错误判断. 例如, 根据国家卫生健 康委员会疫情通报的数据, 截至 2 月 16 日24时止，全国累计确诊病例70548人， 累计出院 10844 人, 累计死亡 1770 人, 计算出治愈率为 $15.37 \%$, 病死率为 $2.51 \%$ ，而留院治疗率高达 $82.12 \%$ ．显 
然, 治愈率为 $15.37 \%$ 和病死率 $2.51 \%$ 不 是新冠肺炎的真实治愈率和病死率, 也不能准确反映目前这么庞大的留院 治疗人群的治疗趋势. 如果用结束医 治的病例样本即累计出院 10844 人和累 计死亡 1770 人来计算, 治愈率为 $85.97 \%$, 病死率为 $14.03 \%$, 我们认为 这也不能提供足够有用的信息. 因此, 我们提出了一种疫情持续过程中估测 新冠肺炎治愈率或病死率的方法, 对 新冠肺炎的治愈率和病死率进行了估 计, 以期为疫病的诊疗和防控提供重 要的参考指标.

\section{1 材料与方法}

（i ）数据来源. 武汉市卫生健 康委员会、湖北省卫生健康委员会、 国家卫生健康委员会发布的 1 月 20 日 至3月 19 日期间的数据, 包括确诊、死 亡及出院人数等 (表S1).

(ii) 治愈率和病死率的定义、模 型及其校正. “治愈”是已经结束医治而 出院，“病死”是因死亡而结束医治. 如 果疫情已经结束而且全部患者也已经 结束医治, 设累计出院人数为 $\sum x$, 累 计病死人数为 $\sum y$, 则累计确诊人数为 $\left(\sum x+\sum y\right)$, 于是

治愈率 $(p)=\left(\sum x\right) /\left(\sum x+\sum y\right)$,

病死率 $(q)=1-p=1-$ 治愈率

$$
=\left(\sum y\right) /\left(\sum x+\sum y\right) \text {. }
$$

由于新冠肺炎疫情正在发生过程 中, 新冠肺炎确诊人群中有治愈出院 的、病死的和在院治疗的. 在院治疗的 确诊人员, 最终是治愈还是病死暂不 清楚, 所以在疫情发生过程中推断疫
情发展趋势, 直接采用上式计算治愈 率或病死率是不恰当的.

根据临床研究结果, 新冠肺炎属 于一种自限性疾病, 早期症状较轻, 到了一周之后, 可能会出现病情加重, 只要病人度过最危险的一段时间即可 逐渐康复. 并且, 根据治疗方案, 治愈 的患者必须待所有症状消失、两次核 酸检测呈阴性, 并隔离数天后方可出 院. 换而言之, 每天公布的病死患者 与出院患者并非同一时间人院的患者, 对于同期的确诊人员, 治愈出院与病死 的病例之间有一个时间差 $(j$ 天). 因此, 我们提出治愈率估计值应当是当日累 计出院人数 $\left(\sum x_{i}\right)$ 与当日累计出院人数 $\left(\sum x_{i}\right)$ 同 $\mathrm{j}$ 天前的累计死亡人数 $\left(\sum y_{i-j}\right)$ 之 和 $\left(\sum x_{i}+\sum y_{i-j}\right)$ 的比率, 即 治愈率 $(p)=\sum x_{i} /\left(\sum x_{i}+\sum y_{i-j}\right)$, 病死率 $(q)=1-$ 治愈率

$$
=\sum y_{i-j} /\left(\sum x_{i}+\sum y_{i-j}\right) \text {. }
$$

在疫情通报中, 还有每天新增的 出院人数 $\left(x_{i}\right)$ 和新增的死亡人数 $\left(y_{i}\right)$, 这每一天的数据也可视为一个个小样 本, 同样符合上述原理, 可以采用公 式(3)和 (4) 相似的形式 $\left[\left(x_{i}\right) /\left(x_{i}+y_{i-j}\right)\right]$ 进 行计算, 可以用来验证由累计数据所 得到的估计值. 不过, 依据单日数据 的估计值肯定比基于累计数据的估计 值, 其稳定性略差.

(iii) $j$ 值确定. 根据统计学理论, 如果新冠肺炎疫情事件满足统计学的 随机事件假设, 在不考虑未来特效药、 特效医疗手段的发现，则每天治愈率 和病死率的估计值理论上应该是基本 稳定的. 按照这一思路, 可以利用公
式(3)对实际数据进行模拟计算, 以治 愈率逐日估计值的方差或变异系数最 小为选择指标, 选定 $j$ 值, 并参照临床 观察统计数据确定 $j$ 的最佳值.

\section{2 结果}

\section{$2.1 j$ 值}

由于 2 月 12 日诊断标准变化, 导 致病例暴增，因此只选用2月11日前的 数据. 以全国数据为例, 从 2 月 11 日开 始往回追溯到 1 月 20 日，在公式(3)中 分别带人 $j=1,2, \cdots \cdots, 15$, 逐天计算 治愈率，结果发现，当 $j=10$ 时，治愈率 的估计值在各天间最稳定，其变异系 数最小.

根据公开的数据，还按武汉、湖 北、湖北除汉、全国除鄂的划分数据 进行了相同的计算, $j$ 值与变异系数之 间的关系见图1. 由图1可见，武汉、全 国、湖北除汉、湖北、全国除鄂的治 愈率估计值的变异系数分别在 $j=8,10$, $10,10,12$ 时达到最小值，说明这是各 天的估计值差异最小.

\section{2 治愈率和病死率}

针对 $j=8,9,10$, 按全国、武汉、湖 北、湖北除汉、全国除鄂的划分, 分别 计算3月 19 日开始回溯逐日的治愈率, 包括按照累计数据和单日新增数据的 计算，全国的治愈率估计值为 $95.74 \%$ $95.78 \%$, 病例病死率约为 $4.22 \%$ 4.26\% (表1，表S2 4).

以 $j=9$ 的结果为例(表 1 , 图2)推测, 新冠肺炎全国的治愈率为 $95.8 \%$ 左右,

表 1 治愈率估计值(\%)

\begin{tabular}{|c|c|c|c|c|c|c|c|c|c|c|}
\hline \multirow[b]{2}{*}{$j$} & \multicolumn{2}{|c|}{ 全国 } & \multicolumn{2}{|c|}{ 武汉 } & \multicolumn{2}{|c|}{ 湖北省 } & \multicolumn{2}{|c|}{ 湖北省(除武汉) } & \multicolumn{2}{|c|}{ 全国(除湖北省) } \\
\hline & $\begin{array}{l}\text { 累计 } \\
\text { 病例 }\end{array}$ & $\begin{array}{l}\text { 每日新 } \\
\text { 增病例 }\end{array}$ & $\begin{array}{l}\text { 累计 } \\
\text { 病例 }\end{array}$ & $\begin{array}{l}\text { 每日新 } \\
\text { 增病例 }\end{array}$ & $\begin{array}{l}\text { 累计 } \\
\text { 病例 }\end{array}$ & $\begin{array}{l}\text { 每日新 } \\
\text { 增病例 }\end{array}$ & $\begin{array}{l}\text { 累计 } \\
\text { 病例 }\end{array}$ & $\begin{array}{l}\text { 每日新 } \\
\text { 增病例 }\end{array}$ & $\begin{array}{l}\text { 累计 } \\
\text { 病例 }\end{array}$ & $\begin{array}{l}\text { 每日新 } \\
\text { 增病例 }\end{array}$ \\
\hline 8 & 95.74 & 98.52 & 94.45 & 98.89 & 95.03 & 98.60 & 96.45 & 96.34 & 99.12 & 96.43 \\
\hline 9 & 95.75 & 97.07 & 94.47 & 97.05 & 95.04 & 96.97 & 96.46 & 96.34 & 99.13 & 100 \\
\hline 10 & 95.78 & 97.72 & 94.51 & 97.50 & 95.08 & 97.64 & 96.48 & 98.75 & 99.13 & 100 \\
\hline
\end{tabular}

Table 1 Estimates of the cure ratio 

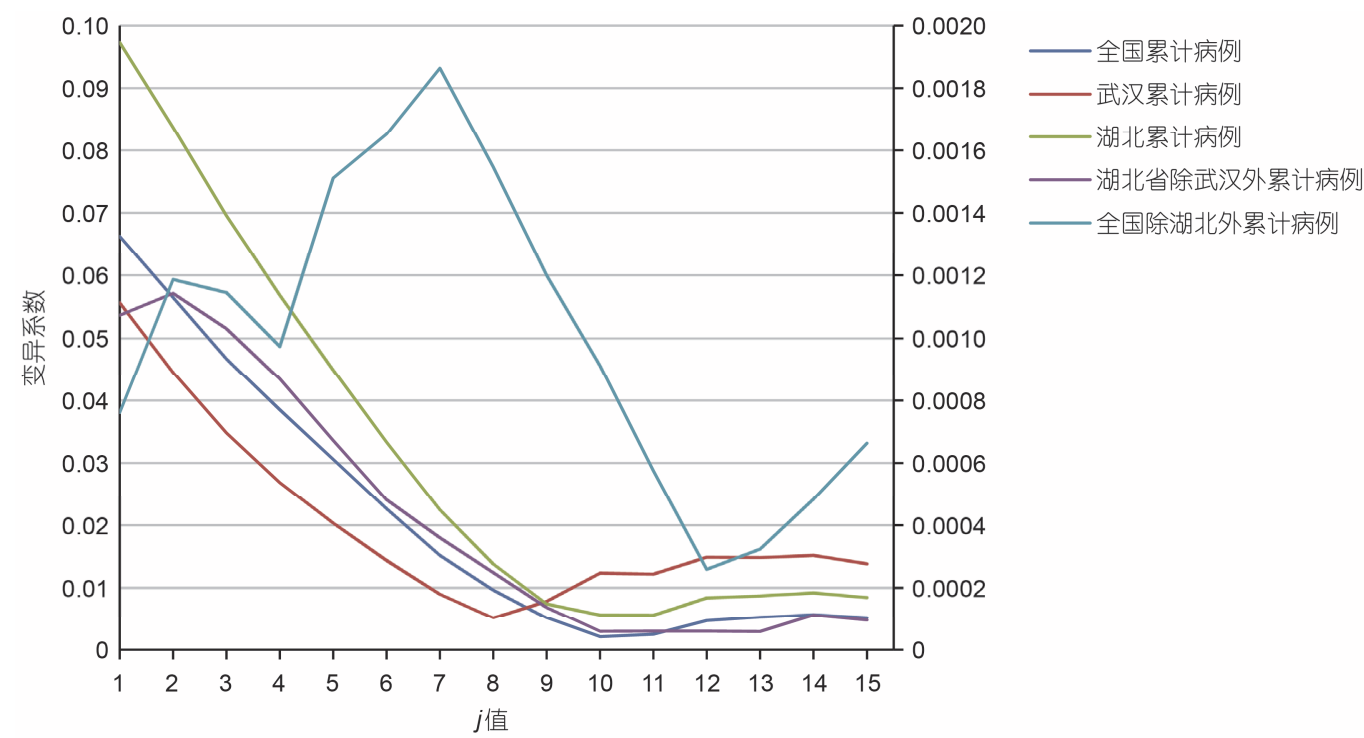

图 1 不同 $j$ 值下治愈率估计值 $(p)$ 的变异系数

Figure 1 Variation coefficient in estimated cure rate $(p)$ at different $j$ values

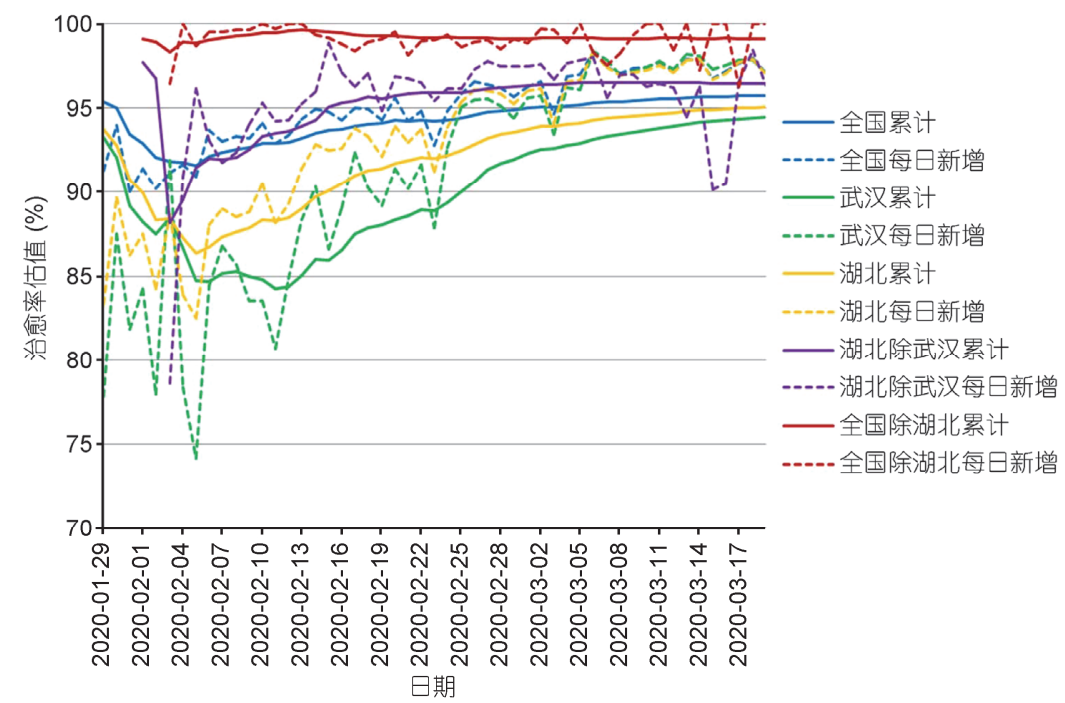

图 $2 j=9$ 时治愈率的估计值

Figure 2 Estimates of cure ratio $(j=9)$

而新冠肺炎全国的病死率为 $4.2 \%$ 左右, 这比 2003年SARS疫情中国大陆的病 死率6.6\%低. 新冠肺炎武汉市的治愈 率为 $94.5 \%$ 左右, 而新冠肺炎武汉市的 病死率则在 $5.5 \%$ 左右. 由于武汉的病 例多、治愈率低, 使得湖北全省的治愈 率低于全国的平均水平. 湖北除汉的 结果与全国平均水平相近. 全国除鄂 外的治愈率高, 这可能与湖北之外的 省份输人性病例较多、输人性病例年
龄结构不一样、病人相对较少而救治 条件较好等因素有关.

\section{3 讨论}

\section{1 关于 $j$ 值}

新冠肺炎疫情来得突然, 怎样治 愈新冠患者, 没有治疗经验, 没有特效 药，治疗以对症支持治疗为主，病愈依 靠自身的免疫力. 假定新冠肺炎疫情
事件满足统计学的随机性、病毒没有变 异，在一定时间内，采用大致相同的医 疗手段与措施, 则每天的治愈率和病 死率应该是基本稳定的, $j=9$ 时的估计 值基本能够满足这一条件. 根据临床 经验，病情加重的时间点更多的是集 中在病程第9 12天，患者病情加重后 有快速进展的过程, 极易出现死亡 $亡^{[14]}$. 本文中 $j=9$ 符合病程的发展规律. 并且, 根据国家卫生健康委员会2月 4 日的新 
闻发布会公布的数据, 出院患者的平 均住院日, 除了湖北以外, 全国出院患 者的平均住院日是 9 天多一点, 湖北省 平均住院日是 20 天 $^{[13]}$, 本文中 $j=9$ 正好 符合该病的实际治疗区间。

治愈率估计值与 $j$ 值大小呈正相 关关系, $j$ 值越大治愈率估计值越大, $j$ 值越小治愈率估计值越小. 治愈率、病 死率的估计值会随 $j$ 值不同而变化, 所 以, 要想获得准确的治愈率、病死率的 估计值, 选择 $j$ 值至关重要, 这也是值 得进一步研究的问题. 不过, 在疫情 持续中, 运用这一策略和方法, 肯定 比直接“用累计出院人数 $\left(\sum x_{i}\right)$ 和累计 死亡人数 $\left(\sum y_{i}\right)$ 与累计确诊病例数之 比, 来分别计算全国新冠肺炎的治愈 率和死亡率” 要科学得多. 而且, 公式 (3)和(4)不仅在疫情持续过程中是恰当 的、适用的, 疫情末期乃至结束后, 用 公式(3)和(4)估计的结果与由公式(1)、 (2)给出的结果相同, 也是准确估计值.

近日, 伦敦帝国理工大学的研究 者通过新构建的模型预测 COVID-19
在海外的病死率为 $1.2 \%$ 5.6\%, 但湖 北省的病死率为 $18 \%{ }^{[15]}$. 他们与我们 同时注意到了在统计病死率时, 选取 的数据忽视了庞大的在院治疗人群. 然而, 他们的模型基于从发病初始到 死亡或者治愈之间的时间差为基础, 但实际上该病发病出现症状与普通流 感极为相似, 这个时间差难以准确判 定; 此外, 湖北省的病死率为 $18 \%$ 的估 计值是基于武汉早期的病例为基础, 早期病例病程长, 病死率高, 由此带 来的估计值偏高.

\section{2 关于治愈率与病死率}

本研究修正了在计算新冠肺炎治 愈率中存在的问题, 以 2 月 16 日为例, 官方公布的2月16日的全国的治愈率仅 为 $15.37 \%$, 我们估计出新冠肺炎全国 的治愈率约为 $93 \%$, 武汉的治愈率为 $87 \%$ 左右, 远高于目前官方公布的数据 (表S2 4). 我们估算出的较高的治愈率 不仅有助于提振全国抗疫的士气, 缓 解群众的焦虑情绪, 同时也可为防控
疫病的决策提供较为科学的依据.

在疫情早期, 武汉金银潭医院, 前 41 例新冠患者死亡率 $15 \%{ }^{[9,16]}$, 前 99 例的死亡率 $11 \%{ }^{[17]}$. 武汉大学中南医 院的临床特征分析中病死率为 $4.3 \%{ }^{[18]}$. 由于武汉地区病人数增长过 快、医治条件不足、诊断不及时治疗 延误, 以及早期对这个病毒的认识不 够影响了救治效果, 导致了临床及预 测均呈现较高的病死率. 《中国-世界 卫生组织新型冠状病毒肺炎 (COVID19)联合考察报告》中指出截至2月20 日中国新冠肺炎的粗病死率约为 $3.8 \%{ }^{[19]}$, 本研究以 3 月 19 日的数据获 得的新冠肺炎全国的病死率估计值为 $4.2 \%$ 左右, 而武汉的病死率估计值为 $5.5 \%$ 左右, 这本质上还是 9 天前 $(3$ 月 10 日)的病死率估计值. 进一步, 我们预 测, 武汉最终的新冠肺炎病死率估计 值可能在 $5.1 \%$ 左右, 因为, 3 月 10 日到 3 月 19 日新增死亡 94 人, 新增出院 9560 人, 3 月 19 日的在院治疗患者还有 6118 人, 而新增确诊人数已经为零.

\section{参考文献}

1 WHO. Statement on the second meeting of the International Health Regulations (2005) Emergency Committee regarding the outbreak of novel coronavirus (2019-nCoV). https://www.who.int/news-room/detail/30-01-2020-statement-on-the-second-meeting-of-the-internationalhealth-regulations-(2005)-emergency-committee-regarding-the-outbreak-of-novel-coronavirus-(2019-ncov), 2020-01-30

2 David S H, Esam I A, Madani T A, et al. The continuing 2019-nCoV epidemic threat of novel coronaviruses to global health-The latest 2019 novel coronavirus outbreak in Wuhan, China. Int J Infect Dis, 2020, 91: 264-266

3 Du Toit A. Outbreak of a novel coronavirus. Nat Rev Microbiol, 2020, 18: 123

4 Peng Z, Xing L Y, Zheng L S, et al. A pneumonia outbreak associated with a new coronavirus of probable bat origin. Nature, 2020, 579: 270-273

5 Callaway A, Cyranoski D. Why snakes probably aren't spreading the new China virus. Nature, 2020, doi: 10.1038/d41586-020-00180-8

6 Qiu T Y, Mao T T, Wang Y, et al. Identification of potential cross-protective epitope between 2019-nCoV and SARS virus. J Genet Genomics, 2020, doi: 10.1016/j.jgg.2020.01.003

$7 \mathrm{Lu} \mathrm{R}$, Zhao X, Li J, et al. Genomic characterization and epidemiology of 2019 novel coronavirus implications for virus origins and receptor binding. Lancet, 2020, 395: 565-574

8 Chen N N, Zhou M, Dong X, et al. Epidemiological and clinical characteristics of 99 cases of 2019 novel coronavirus pneumonia in Wuhan, China: A descriptive study. Lancet, 2020, 395: 507-513

9 Huang C L, Wang Y M, Li X, et al. Clinical features of patients infected with 2019 novel coronavirus in Wuhan, China. Lancet, 2020, 395: 497-506

$10 \mathrm{Xu} \mathrm{X}$, Chen P, Wang J, et al. Evolution of the novel coronavirus from the ongoing Wuhan outbreak and modeling of its spike protein for risk of human transmission. Sci China Life Sci, 2020, 63: 457-460

11 John N. China's response to a novel coronavirus stands in stark contrast to the 2002 SARS outbreak response. Nat Med, 2020, 26: 310-311

12 WHO. Summary of probable SARS cases with onset of illness from 1 November 2002 to 31 July 2003. https://www.who.int/csr/ sars/country/table2004_04_21/en/ 
13 National Health Commission of the People's Republic of China. Press briefing (Feb 04, 2020). http://www.nhc.gov.cn/xwzb/webcontroller.do? titleSeq=11220\&gecstype $=1$ (accessed)

14 National Health Commission of the People's Republic of China. Press briefing (Feb 05, 2020) http://www.nhc.gov.cn/xwzb/webcontroller. do?titleSeq $=11221 \&$ gecstype $=1$

15 Ilaria D, Lucy O, Anne C, et al. Report 4: Severity of 2019-novel coronavirus (nCoV) http://www.imperial.ac.uk/mrc-global-infectiousdisease-analysis/news-wuhan-coronavirus/

16 Zhou X, Shu L, Shen T, et al. Full spectrum of COVID-19 severity still being depicted. Lancet, 2020, 395: 947-948

17 Chen N, Zhou M, Dong X, et al. Epidemiological and clinical characteristics of 99 cases of 2019 novel coronavirus pneumonia in Wuhan, China: A descriptive study. Lancet, 2020, 10233: 507-513

18 Wang D, Hu B, Hu C, et al. Clinical characteristics of 138 hospitalized patients with 2019 novel coronavirus-Infected pneumonia in Wuhan, China. JAMA, 2020, 323: 1061-1069

19 WHO-China Joint Mission. Report of the WHO-China Joint Mission on Coronavirus Disease 2019 (COVID-19). https://www.who.int/ docs/default-source/coronaviruse/who-china-joint-mission-on-covid-19-final-report.pdf

\section{补充材料}

表 S1 原始数据

表 S2 治愈率估计(当 $j=8$ )

表 S3 治愈率估计(当 $j=9$ )

表 S4 治愈率估计(当 $j=10)$

本文以上补充材料见网络版 csb.scichina.com. 补充材料为作者提供的原始数据, 作者对其学术质量和内容负责. 


\title{
Estimating the cure rate and case fatality rate of the ongoing epidemic COVID-19
}

\author{
Ying Diao ${ }^{1 \dagger}$, Xiaoyun Liu $^{3 \dagger}$, Tao Wang ${ }^{2 \dagger}$, Xiaofei Zeng ${ }^{5}$, Chen Dong ${ }^{6}$, Yuanming Zhang ${ }^{7}$, \\ Changlong Zhou ${ }^{8}$, Xuan $\mathrm{She}^{2}$, Dingfu Liu ${ }^{4 *} \&$ Zhongli $\mathrm{Hu}^{2 *}$ \\ ${ }^{1}$ College of Landscape Architecture and Life Sciences, Chongqing University of Arts and Sciences, Chongqing 402160, China; \\ ${ }^{2}$ College of Life Sciences, Wuhan University, Wuhan 430072, China; \\ ${ }^{3}$ Wuhan Windoor Information Technology Co. Ltd., Wuhan 430040, China; \\ ${ }^{4}$ Hubei Academy of Agricultural Sciences, Wuhan 430064, China; \\ ${ }^{5}$ School of Medicine, Southern University of Science and Technology, Shenzhen 518055, China; \\ ${ }^{6}$ College of Biological Engineering, Henan University of Technology, Zhengzhou 450001, China; \\ ${ }^{7}$ College of Plant Science and Technology, Huazhong Agricultural University, Wuhan 430070, China; \\ ${ }^{8}$ Yongchuan Hospital, Chongqing Medical University, Chongqing 402160, China \\ $\dagger$ Equally contributed to this work \\ *Corresponding authors, E-mail: wonderlau@126.com; huzhongli@whu.edu.cn
}

The COVID-19 outbreak has been associated with over 250000 confirmed infections and over 11000 confirmed deaths worldwide. The epidemic poses a huge challenge to global public health security. Cure rate (CR)/case fatality rate (CFR) is an important data to assess the severity of an epidemic disease and an important consideration to evaluate the therapeutic effect. The current calculation of CR or CFR for COVID-19 epidemic is based on formula: number of cure or deaths/number of diagnosed. This calculation method was called crude CR/CFR. However, there is no more scientific method to calculate the CR and CFR of the epidemic due to the changing data of the epidemic, especially the large increase of the number of diagnosed and hospitalized. The estimated CFR calculated by the basic formula is called crude CFR. Considering a large number of hospitalized patients, we revised the calculation method for CR, which is the ratio of cumulative discharges on a given day to the sum of cumulative discharges on a given day and cumulative deaths before $j$ days is used to estimate the CR. In addition, the CFR can be estimated accordingly. According to statistical theory, if the COVID-19 epidemic event satisfies the statistical random event hypothesis, the estimated daily CR and CFR rate should be basically stable without considering the discovery of future special drugs and special medical methods. Therefore, the $j$ value is selected with the minimum variance or coefficient of variation of the daily estimate of $\mathrm{CR}$ as the selection index, and the best value of $j$ is determined by reference to clinical observation statistics. According to the results, the coefficient of variation of the estimated CR of Wuhan, Hubei, China, Hubei excluding Wuhan and China excluding Hubei reached the minimum value at $j=8,10,10,10$ and 12 , respectively, indicating that this is the least difference in the estimated value of each day. When $j=9$, the CR of COVID-19 was estimated to be about $95.8 \%$ in China, while the CFR was estimated to be about $4.2 \%$, which is lower than that of the SARS epidemic in mainland China in 2003; the CR in Wuhan was estimated to be about $94.5 \%$, while the CFR in Wuhan was estimated to be about $5.5 \%$. Because of the large number of cases and low cure rate in Wuhan, the cure rate in Hubei Province is lower than the national average. The CR of Hubei excluding Wuhan was similar to the national average. The CR of China excluding Hubei Province is the highest, which may be related to the factors of more imported cases, different age structure of imported cases, relatively few patients and better treatment conditions in the other provinces. This method of estimating the CR optimized the calculation method of crude $\mathrm{CR}$, considering the influence of the population still in hospital on the valuation. So the comparatively accurate CR/CFR predictions for the ongoing epidemics are conducive to decision making regarding epidemic prevention and control as well as evaluating the curative effects of availed treatments.

COVID-19, SARS-CoV-2, cure ratio, case fatality ratio, estimating

doi: 10.1360/TB-2020-0190 